\title{
FDG-PET で陽性となった肺内リンパ節の一例
}

\author{
池田 敏裕, 奥田 昌也, 徳永 義昌 \\ 喜田 裕介, 横田 直哉, 横見瀬裕保
}

\begin{abstract}
要 旨
FDG-PET で陽性となった肺内リンパ節の 1 症例を報告する. 症例は 77 歳女性. 胸部異常院影を主訴に受診. 胸部 CT で右肺中葉 S5 に $9 \mathrm{~mm}$ 大の spicula を伴う不整な結節影を認めた. FDG-PET では SUVmax : 1.3 となり, 他の組織の集積と 比較して陽性と診断した．悪性疾患の可能性を否定できなかったため, 胸腔鏡下右中葉部分切除術を施行した.

胸腔内は全面に癒着を認め, 過去に胸腔内に炎症が存在したことが示唆された。切除標本は $9 \mathrm{~mm} の$ 黒色結節であり, 病 理診断で結節は境界明暸で類円形〜紡錘形に示す組織球様細胞が線維性結合組織を伴った増生を認め, 部分的に炭粉荟食像 がみられることから肺内リンパ節との診断であった. FDG-PET で集積を示す結節は, 悪性疾患, 炎症性疾患などが鑑別に挙 がるが，炎症の既往があった場合には肺内リンパ節も鑑別候補として考慮する必要がある.
\end{abstract}

索引用語 : 肺内リンパ節, 外科切除, FDG-PET, 胸腔鏡下手術 intrapulmonary lymph node, surgical resection, FDG-PET, video-assisted thoracoscopic surgery

\section{はじめに}

フッ素 18 標識-fluorodeoxyglucose Positron Emission Tomography（以下 FDG-PET）はフッ素 18 標識-fluorodeoxyglucose（以下 FDG）を代謝する細胞への集積を測 定する画像検査で, 肺癌の画像診断において病期診断も 含め有効な検查と言われているが，炎症性疾患など糖代 謝が盛んな細胞にも集積を認めるため擬陽性となること がある. 今回 FDG-PET で陽性となり肺癌と鑑別を要し た肺内リンパ節の 1 例を経験した．FDG-PET 陽性の肺 内リンパ節の報告は，稀なため今回報告する。

\section{症例}

症 例 : 77 歳女性.

主 訴: 胸部異常陰影.

既往歴：特記事項なし.

香川大学医学部呼吸器外科 原稿受付 2016年 4 月 5 日 原稿採択 2016年 7 月14日 本論文の要旨は第 31 回日本呼吸器外科学会総会 (東京) にて 報告を行った。
喫煙歴：なし。

現病歴 : 3 力月前に検診で胸部異常陰影を指摘され近 医を受診. 胸部単純 CT で右肺中葉に辺縁不整な結節を 認め, 肺癌疑いのため当科紹介受診となった。

入院時検査所見：肺癌の腫瘍マーカーはいずれも正常 範囲内であった。

胸部単純 $\mathbf{X}$ 線：右中肺野鎖骨中線上に $9 \mathrm{~mm} の$ 結節 影を認めた（Fig. 1).

胸部 CT : 右肺中葉 S5に $9 \mathrm{~mm}$ 大の spicula を伴う結 節を認めた．前医で施行した CT と比べて結節の大きさ に有意な差は認めなかった（Fig. 2).

FDG-PET : 結節に一致して SUVmax = 1.3 となった. 肺内・肺外の他の組織, リンパ節への有意な集積はなく, その比較から結節はFDG-PETで陽性と診断された (Fig. 3).

画像所見から肺炎や結核などの炎症性疾患を疑った が, spicula の所見や FDG-PET が陽性であったことから 肺癌や転移性肺腫瘍などの悪性疾患の可能性も否定でき なかった．数力月後に胸部 CT で再評価することも検討 したが，早期での手術による診断への患者の強い希望も あり，診断加療目的に手術を施行した。 


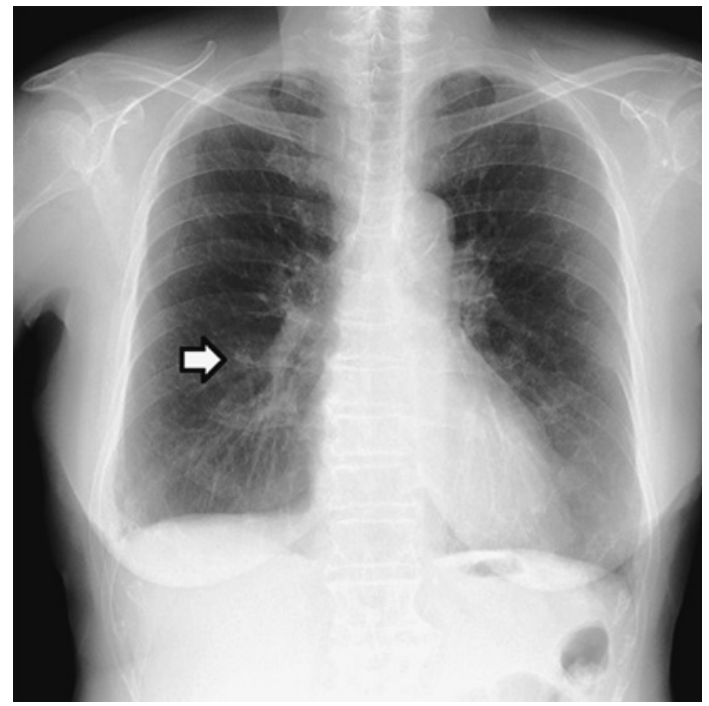

Fig. 1 Chest radiograph showing a 9-mm node in the right middle lung field. (arrow)

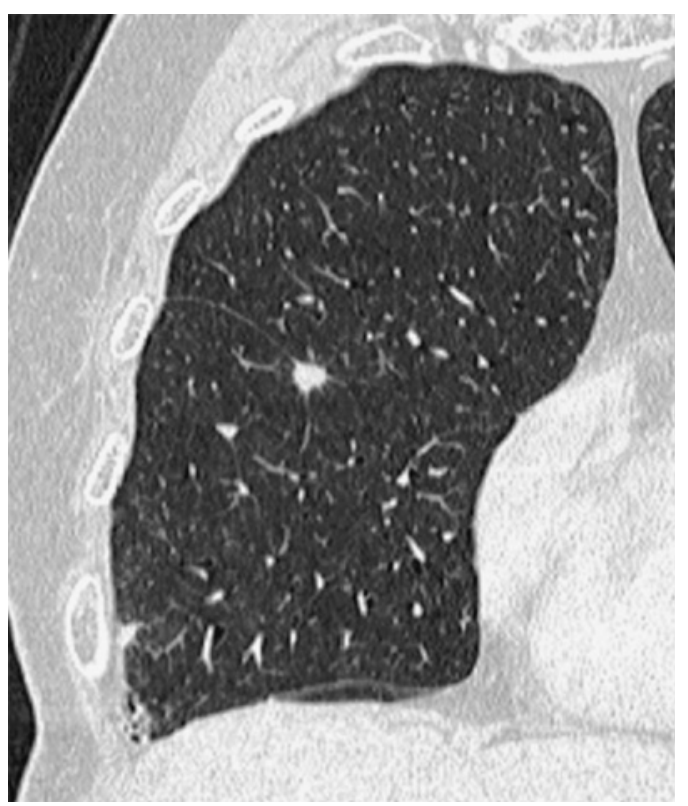

Fig. 2 Chest CT showing a nodal shadow with spiculation in the right middle lobe.

手 術：胸腔鏡下手術でアプローチした。胸腔内は全 面に癒着を認めた。右上中葉間腹側の画像と一致する場 所に $10 \mathrm{~mm}$ 大の硬い結節を認め, これを部分切除した. 切除標本では $9 \mathrm{~mm}$ の黑色結節をみとめ, 迅速病理組織 診の診断は肺内リンパ節で悪性所見は無いとのことで あったため追加切除はせず手術を終了した（手術時間 2 時間 30 分, 出血量 $52 \mathrm{ml}$ ).

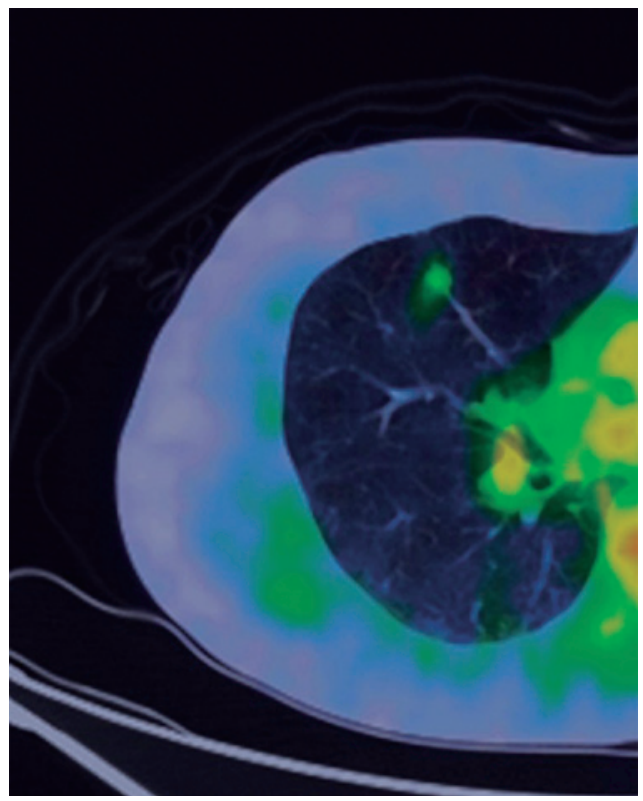

Fig. 3 FDG-PET showing FDG accumulation in the nodal shadow. (SUVmax: 1.3)

病理組織所見：結節は境界明瞭で類円形〜紡錘形に示 す組織球様細胞が線維性結合組織を伴った増生を認め, 部分的に炭粉会食像がみられた。これらのことから肧中 心を伴うリンパ滤胞の構造は見られず，リンパ節の固有 構造は崩れているが肺内リンパ節として矛盾しない像で あった。また，サルコイド様反応は切片中には特に見ら れず，悪性像は認めなかった（Fig.4).

術後経過：経過良好で術後第 9 病日に退院となった.

\section{考察}

1980 年代には, 肺内リンパ節は肺門，中枢気管支周囲 に存在し，第 4 次気管支レベルまでにしか存在しないと 言われていた1). しかし, 近年高分解能 CT の開発, 健診 の普及により，これまで指摘されなかった微小肺腫瘤性 病変が検出されるようになってきており胸膜直下の肺内 リンパ節も報告されている1.

肺内リンパ節の臨床的特徴について Yokomise ら ${ }^{2)}$ は 男性，契煙者に比較的多く，発生しやすい領域は下葉， 胸膜付近と報告している。本症例では女性, 非喫煙者で はあったが配偶者は重喫煙者であり，術中の胸腔鏡で肺 に炭分沈着を認めた. Yokomise ら ${ }^{2)}$ はさらに肺内リンパ 節の CT 所見の特徵を(1)辺縁明瞭であることが多い，(2) 胸膜直下, あるいは数 $\mathrm{mm}$ 以内に存在する, (3)複数個存 在することがある, (4pleural indentation を生ずること 


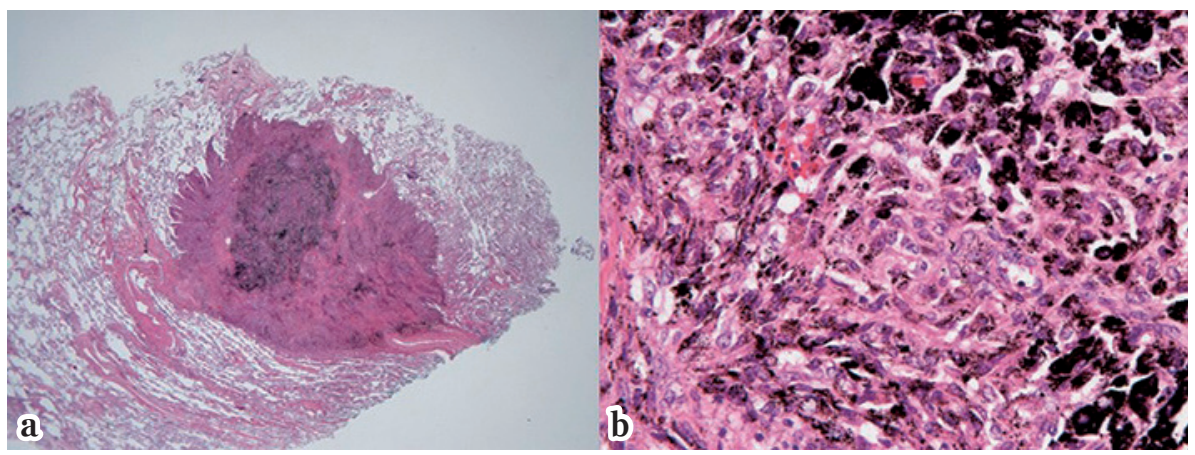

Fig. 4 Histologic section shows inflammatory change with hyperplasia of fibrous connective tissue, and phagocytosis of carbon dust. (Hematoxylin and eosin stain, $\times 20(\mathbf{a}), \times 200(\mathbf{b}))$

がある，(5)辺縁がけばだっていることがある，と報告し ている.また他の報告においても, pleural indentation ${ }^{3} や$ notch $^{4)}$ を伴ったり，血管影との関与 ${ }^{5.6)}$ が示唆される所見 が認められたり， spicula ${ }^{7}$ を伴うこともあったと報告さ れており，これらの所見は小型肺癌でも認められる所見 であるため悪性腫瘍との鑑別が難しいことが示唆され る. 本症例においても spicula を認めており悪性腫瘍の 可能性は画像から完全に否定することはできなかった。

これらのことからも CT 所見からは良性悪性の鑑別は 困難であり Higashi ら ${ }^{8)}$ は腫瘍性病変の良性悪性の診断 をするためにPET に注目した。

FDG-PET と胸部造影 CT に扔ける肺癌の感度は 97\% 程度で同程度であるが, 肺癌診断に対する特異度は胸部 造影 CT が58\%，これに対して FDG-PETは78\% と確 定診断に有用であることが示されている9 ${ }^{9}$. FDG-PET における肺癌の偽陽性率は 30〜 50\% であり, 偽陽性を示 す疾患として, 結核, 膿瘍, サルコイドーシス, 良性腫 瘍(過誤腫, 線維腫, 神経原性腫瘍, 動脈瘤, 硅肺), 肺 内リンパ節が挙げられている10.11). しかし，これまで FDG-PET 陽性肺内リンパ節の報告は少ない. また, 直径 $10 \mathrm{~mm}$ 未満の結節やスリガラス様陰影が主体の肺悪性 結節においては偽陰性を呈することがあるとの報告があ る $^{12,13)}$.

FDG-PET はブドウ糖の類似物質である 18F-FDGを 用いて, 悪性腫瘍などの糖代謝の㠵進している細胞を検 出するのに有用である ${ }^{14)}$. 一方, 炎症性疾患でも種々の程 度にFDG が集積し，悪性腫瘍と鑑別しにくい所見を呈 することがあることが知られている ${ }^{15)}$.

一般的に, 炎症局所では血流が増加し, 毛細血管の拡
張・破綻・新生があり，血液成分の漏出とともに炎症細 胞（顆粒球・リンパ球・マクロファージなど）が浸潤す るが, 線維芽細胞の増殖・コラーゲン産生により線維化 も生じる。これらの過程で嫌気性解糖をエネルギー源と している活性化リンパ球，マクロファージ，顆粒球には とくに FDGが集積しやすいとされている ${ }^{15)}$. 今回の症例 において結核や肺炎といった感染の既往は無かったが, 手術所見で胸腔内に高度の炎症の痕跡があることから， 過去に胸腔内に炎症が存在したことが示唆され，胸腔内 に残存していた炎症性変化の影響によって肺内リンパ節 に FDG が集積したと考察される。

FDG-PET の集積におけるカットオフについては, 様々な報告があるが明確な基準は定まっていない，Khalaf $~^{16)}$ は $10 \mathrm{~mm}$ を超える肺内結節に対してはSUVmax のカットオフ值を 2.5 とすることが有用であるとしてい るが, $10 \mathrm{~mm}$ 以下の場合には明確なカットオフ值を示し ていない.これは SUV の計算式が(PET 装置の関心領域 に扔ける組織放射能 $(\mathrm{MBq} / \mathrm{g}) \div[\mathrm{FDG}$ 投与量 $(\mathrm{MBq}) /$ 体重 $(\mathrm{g})$ 】】で示されるように腫瘍の大きさが関係してい ないため大きさによってカットオフ值を定められないか ら，とされている ${ }^{17}$ 。 また, SUVmax は放射性薬剤投与 後撮像までの時間・装置と撮像条件(分解能と雑音) - 体 型・腎機能に影響を受けるため施設毎・患者毎による差 があり，明確なカットオフ值は設定できないから，とさ れている ${ }^{177}$.炎症性疾患の方が FDG 集積のピークが 1 時間以内のことが多く, クリアランスも早いのに対し, 悪性疾患ではそのピークが 1 時間よりももっと遅いとさ れ，遅延相を撮影することにより診断精度が上がるとい う報告もある ${ }^{18}$. しかし, 炎症性変化と悪性腫瘍ではピー 
クがオーバーラップされている報告もあり, 診断は困難 となる ${ }^{18)}$. 本症例においては早期相で FDG-PET 陽性と なっており CT 画像の性状と合わせて肺癌が疑われたた め遅延相の撮影は行われなかった.

\section{結語}

今回，我々は FDG-PET 陽性となった肺内リンパ節の 一例を経験した. FDG-PET で陽性となる肺内結節は, 炎 症性変化を伴った肺内リンパ節の可能性も考慮する必要 がある。

\section{利益相反}

本論文について申告する利益相反はない.

\section{文献}

1. 中川義久, 築山邦規, 中島正光, 梅木茂宣, 日野二郎, 沖 本二郎, 他. 結節影を呈した胸膜下リンパ節腫大の 1 例. 日胸臨 1989; 48: 849-52.

2. Yokomise H, Mizuno H, Ike O, Wada H, Hitomi S, Itoh H. Importance of Intrapulmonary Lymph Nodes in the Differential Diagnosis of Small Pulmonary Nodular Shadows. Chest 1998; 113: 703-6.

3. 常塚宣男, 斎藤 裕, 増田信二, 北川正信. びまん性沉細 気管支炎経過観察中に画像上出現した胸膜下肺内リンパ 節の 1 例. 日胸臨 1994; 53: 278-83.

4. Benisch B, Peison B, Osborne A. An intrapulmonary lymph node presenting as a coin lesion of the lung. Chest 1979; 76: 336-7.

5. 橋本吉弘, 滝下佳宽, 坂東弘康, 佐野隆宏, 長野 貴, 仁 木俊輔, 他. 肺癌と鑑別困難であった珪酸結節を伴う肺内 リンパ節の1 例. 日胸疾患会誌 1990; 28: 1230-3.

6. 磯部 威, 津谷隆史, 由田康弘, 立山義朗, 村上 功, 山 木戸道郎，他. 肺癌との鑑別を要した肺内リンパ節の 1 例. 日胸臨 1992; 51: 483-6.

7. 雨宮徳直, 西 耕一, 水口雅之, 大家他喜雄, 小林孝一郎, 佐藤日出夫, 他. 両側多発小結節陰影を呈した肺内リンパ 節の 1 例. 日胸疾患会誌 1995; 33: 478-82.

8. Higashi K, Nishikawa T, Seki H, Oguchi M, Nambu Y, Ueda Y, et al. Comparison of fluorine-18-FDG PET and thallium-201 SPECT in evaluation of lung cancer. J Nucl
Med 1998; 39: 9-15.

9. Gould MK, Maclean CC, Kuschner WG, Rydzak CE, Owens DK. Accuracy of positron emission tomography for diagnosis of pulmonary nodules and mass lesions: a meta-analysis. JAMA 2001; 285: 914-24.

10. Shiraki N, Hara M, Ogino H, Shibamoto Y, Iida A, Tamaki T, et al. False-positive and true-negative hilar and mediastinal lymph nodes on FDG-PET-radiologicalpathological correlation. Ann Nucl Med 2004; 18: 23-8.

11. Roberts PF, Follette DM, von Haag D, Park JA, Valk PE, Pounds TR, et al. Factors associated with false-positive staging of lung cancer by positron emission tomography. Ann Thorac Surg 2000; 70: 1154-9.

12. Lindell RM, Hartman TE, Swensen SJ, Jett JR, Midthun DE, Nathan MA, et al. Lung cancer screening experience: a retrospective review of PET in 22 non-small cell lung carcinomas detected on screening chest $\mathrm{CT}$ in a high-risk population. AJR Am J Roentgenol 2005; 185: 126-31.

13. Fortes DL, Allen MS, Lowe VJ, Shen KR, Wigle DA, Cassivi SD, et al. The sensitivity of 18F-fluorodeoxyglucose positron emission tomography in the evaluation of metastatic pulmonary nodules. Eur J Cardiothorac Surg 2008; 34: 1223-7.

14. 小口和浩. FDG-PET の原理と臨床的有用性. 治療 2005; 87: 2948-55.

15. 小林 弘, 雫石一也, 石ヶ坪良明. 炎症性疾患に扔ける 18FDG-PET の有用性.リウマチ科 2005; 33: 318-28.

16. Khalaf M, Abdel-Nabi H, Baker J, Shao Y, Lamonica D, Gona J. Relation between nodule size and 18F-FDG-PET SUV for malignant and benign pulmonary nodules. J Hematol Oncol 2008; 1: 13.

17. 細野 眞, 佐賀恒夫, 伊藤健吾, 汲田伸一郎, 佐々木雅之, 千田道雄, 他. FDG PET, PET/CT 診療ガイドライン 2012. 核医学 2012; 49: 391-401.

18. Nakamoto Y, Higashi T, Sakahara H, Tamaki N, Kogire M, Doi R, et al. Delayed 18F-fluoro-2-deoxy-D-glucose positron emission tomography scan for differentiation between malignant and benign lesions in the pancreas. Cancer 2000; 89: 2547-54. 


\title{
A case of intrapulmonary lymph node with FDG accumulation
}

\author{
Toshihiro Ikeda, Masaya Okuda, Yoshimasa Tokunaga \\ Yusuke Kita, Naoya Yokota, Hiroyasu Yokomise \\ Department of General Thoracic Surgery, Faculty of Medicine, Kagawa University
}

A 77-year-old woman was admitted to our hospital with a chest nodal shadow. Chest CT showed a 9-mm nodule with spiculation in the right middle lobe. We resected the nodule by video-assisted thoracoscopic surgery. There was inflammatory adhesion in the right intrathoracic cavity. It was suggested that the inflammation had been present in the intrathoracic cavity previously. Histopathological findings of the nodule were inflammatory change with hyperplasia of fibrous connective tissue, and phagocytosis of carbon dust. The nodule was an intrapulmonary lymph node. At 9 days after the operation, the patient was discharged from our hospital without any problems.

Fluorine-18-fluorodeoxyglucose accumulation on positron emission tomography is effective to distinguish between malignant tumors and others. However, we report the case of an intrapulmonary lymph node presenting with a lung cancer-like shadow and fluorine-18-fluorodeoxyglucose accumulation on positron emission tomography. Because intrapulmonary lymph nodes influenced by inflammatory disease could accumulate fluorine-18-fluorodeoxyglucose on positron emission tomography, we should take into account intrapulmonary lymph nodes, even if nodules accumulate fluorine-18-fluorodeoxyglucose on positron emission tomography.

(C) The Japanese Association for Chest Surgery (JACS) 